\title{
Pengembangan Media Pembelajaran Variasi Permainan Karate yang dikemas Dalam Articulate Storyline
}

\author{
Aisyah Kartika Dewi*, Ari Wibowo Kurniawan \\ Universitas Negeri Malang, Jl. Semarang No. 5 Malang, Jawa Timur, Indonesia \\ *Penulis korespondensi, Surel: aisyahkartika1999@gmail.com
}

Paper received: 24-5-2021; revised: 14-6-2021; accepted: 21-6-2021

\begin{abstract}
Current learning conditions, prevalence of the corona outbreak has resulted in education in Indonesia being affected by this virus outbreak, so that formal education that has been carried out so far is replaced by education through an online system, the distance education in question is education carried out by means of online. With the current online learning model, the tools needed by educators so that learning continues well and can be accepted by students, one of which is learning media in the form of applications. The purpose of this research is to develop learning karate martial arts in the form of an articulate storyline application and can help facilitate teachers in the learning process of karate martial arts in Sukun District, Malang City. The development method used leads to development research according to Lee and Owens. The results of evaluation learning experts were obtained 74 percent, the results of evaluation the media experts were obtained 97 percent, the results of expert analysis the games were obtained 96 percent, the results of analysis the PJOK experts were obtained 75 percent, the results of analysis the karate experts were obtained 75 percent, the results of small group trial were obtained 86 percent and the results large group trials obtained 88 percent. Based on these results, it is concluded that the products produced are stated to have accuracy, attractiveness, suitability, ease, clarity, and effectiveness for use.
\end{abstract}

Keywords: learning media; game; karate

\begin{abstract}
Abstrak
Kondisi pembelajaran saat ini, maraknya wabah corona mengakibatkan pendidikan di Indonesia terdampak akibat wabah virus ini, sehingga pendidikan formal yang dilakukan selama ini diganti dengan pendidikan melalui sistem dalam jaringan, pendidikan jarak jauh yang dimaksud adalah pendidikan yang dilakukan dengan cara online atau daring. Dengan model pembelajaran daring saat ini, alat bantu yang diperlukan pendidik agar pembelajaran tetap berlangsung dengan baik dan dapat diterima oleh siswa salah satunya media pembelajaran yang berupa aplikasi. Tujuan dari penelitian ini adalah untuk mengembangkan pembelajaran bela diri karate dalam bentuk aplikasi articulate storyline dan dapat membantu memudahkan guru dalam proses pembelajaran materi bela diri karate di Kecamatan Sukun Kota Malang. Metode pengembangan yang digunakan mengarah pada penelitian pengembangan menurut Lee dan Owens. Hasil evaluasi ahli pembelajaran diperoleh 74 persen, hasil evaluasi ahli media diperoleh 97 persen, hasil analisis ahli permainan diperoleh 96 persen, hasil analisis ahli PJOK diperoleh 75 persen, hasil analisis ahli karate diperoleh 75 persen, hasil uji coba kelompok kecil diperoleh 86 persen dan hasil uji coba kelompok besar diperoleh 88 persen. Berdasarkan dari hasil tersebut disimpulkan bahwa produk yang dihasilkan dinyatakan memiliki ketepatan, kemenarikan, kesesuaian, kemudahan, kejelasan, dan keefektifan untuk digunakan.
\end{abstract}

Kata kunci: media pembelajaran; permainan; karate

\section{Pendahuluan}

Pendidikan jasmani adalah media pembelajaran yang dapat mengembangkan suatu keterampilan motorik siswa, fisik, serta pengetahuan tentang pola hidup sehat untuk membentuk karakter siswa dan dapat mencapai tujuan pendidikan. Sistem Pendidikan Nasional. Menurut (Bangun, 2016) Pendidikan jasmani dan olahraga merupakan suatu proses 
yang dilaksanakan mulai pendidikan paling dasar sampai pendidikan menengah yang didalamnya terdapat aktivitas fisik dan proses mencapai kebugaran jasmani serta terdapat keterampilan gerak yang dapat mempengaruhi kemampuan sikap serta intelektual kehidupan sehari-hari. Dapat disimpulkan pendidikan jasmani merupakan proses belajar mengajar yang dilaksanakan mulai dari tingkat dasar pendidikan yaitu sekolah dasar sampai sekolah menengah yang memiliki tujuan untuk mengembangkan keterampilan siswa yaitu kognitif, afektif, dan psikomotor melalui aktivitas jasmani.

Di dalam kegiatan pembelajaran terdapat mata pelajaran pendidikan jasmani. Pembelajaran dapat diartikan sebagai bertambahnya wawasan ilmu yang lebih luas untuk menjadi modal ilmu ke jenjang yang lebih tinggi. Menurut (Hanafy, 2014), Pembelajaran adalah proses terjadinya pemerolehan pengetahuan yang diwujudkan oleh pendidik serta penguasaan materi dan pembentukan karakter pada siswa. Dengan kata lain, pembelajaran adalah proses yang menerapkan siswa memperoleh pembelajaran dengan baik. Sehingga dengan demikian pendidik perlu penguasaan teori-teori yang disampaikan dan dapat menjadi landasan pelaksanaan pembelajaran untuk menghasilkan proses belajar mengajar yang efektif dan menarik,. Dapat disimpulkan pembelajaran adalah proses interaksi antara siswa dan guru pada suatu lingkungan belajar untuk mencapai suatu hasil yang optimal.

Dalam pembelajaran terdapat media pembelajaran yang berperan penting di dalamnya untuk memfasilitasi berlangsungnya sebuah proses pembelajaran. Media pembelajaran merupakan suatu alat yang dapat membantu menyampaikan sebuah materi dalam proses belajar mengajar sehingga memudahkan pencapaian tujuan pembelajaran. Menurut (Dwijayani, 2019) Media Pembelajaran adalah sebuah alat yang dapat menyampaikan sebuah materi menjadi lebih jelas serta membantu proses belajar mengajar sehingga dapat menjadikan materi tersebut menjadi lebih efektif dan efisien dengan penjelasan yang sistematis dan menarik.

Media pembelajaran yang digunakan oleh peneliti berupa aplikasi yaitu aplikasi Articulate Storyline. Articulate storyline salah satu media pembelajaran yang dapat berupa teks, gambar, audio, video, dan animasi yang bersifat interaktif yang digunakan untuk menyampaikan informasi. Menurut (Salam, 2017) Articulate Storyline adalah perangkat lunak yang dapat diakses secara offline dan dapat diaplikasikan pada laptop maupun smartphone juga sebagai alat yang berfungsi untuk mencapai pembelajaran yang interaktif. Untuk itu perlu dipelajari dalam menciptakan sebuah presentasi dan bagaimana cara merencanakan sebuah storyline project, dengan menggunakan semua alat dan elemen yang berbeda, dan dapat diaplikasikan dalam sebuah media seperti audio dan video, serta menggunakan fasilitas Storyline quiz dan mempublikasikannya. Jadi aplikasi articulate storyline dapat meningkatkan minat peserta didik dalam proses belajar dan digunakan sebagai media pembelajaran , aplikasi yang penuh dengan fitur-fitur menarik di dalamnya serta dapat menambah wawasan pendidik.

Pada mata pelajaran PJOK yang diajarkan di kelas IV SD, diantaranya adalah gerak lokomotor dan gerak non-lokomotor. Gerak lokomotor adalah gerakan tubuh yang berpindah tempat. Di sekolah dasar umumnya gerak lokomotor yang sering dijumpai yaitu lari, jalan, lompat, dan loncat. Namun pada penelitian ini, penulis memilih salah satu materi berupa olahraga karate (Hanief \& Sugito, 2015). Gerakan non lokomotor adalah gerakan yang terjadi pada seluruh anggota tubuh dan tidak berpindah tempat. Menghindar, memutar dan berputar, meregangkan otot, bergantung, menarik, mengayunkan kaki, dan mendorong adalah beberapa 
gerakan nonlokomotor (Hanief \& Sugito, 2015). Dalam gerak lokomotor terdapat materi karate yang dipilih oleh peneliti. Karate adalah salah satu beladiri yang diajarkan di jenjang sekolah dasar, materi beladiri karate dapat mengembangkan keterampilan motorik peserta didik, serta dapat meningkatkan kebugaran jasmani. Karate adalah cabang olahraga atau seni bela diri dari jepang dan dapat disebut dengan suatu teknik beladiri tidak menggunakan senjata, beladiri karate memiliki tujuan utama, yakni untuk pertahanan sekaligus pelindung diri dari berbagai ancaman dan juga olahraga yang dapat menjaga kondisi tubuh. Pada tahap ini sebagian besar anak didik lebih menyukai proses pembelajaran yang lebih banyak mengandung unsur permainan. Permainan merupakan kegiatan yang dapat membuat seseorang merasa senang dan dapat dilakukan oleh siapa saja, anak akan merasa senang jika suatu pembelajaran pendidikan jasmani memberikan sebuah permainan di dalamnya (Setiawan \& Triyanto, 2014) Jadi permainan adalah suatu kegiatan diluar maupun didalam ruangan, bersifat menyenangkan yang bisa dilakukan oleh siapa saja dengan 2 macam permainan yaitu tradisional dan modern. Pada saat ini anak-anak lebih mendominasi mengarah pada permainan modern melalui smartphone sehingga kurangnya aktivitas gerak pada anak.

Semakin modernnya teknologi saat ini, terdapat banyak media pembelajaran yang menarik, dan juga dengan model pembelajaran daring saat ini, alat bantu yang diperlukan pendidik agar pembelajaran tetap berlangsung dengan baik dan dapat diterima oleh siswa salah satunya multimedia berupa aplikasi. Saat ini aplikasi yang sudah banyak digunakan antara lain google classroom, google meet, zoom, whatsapp dan beberapa aplikasi lainnya. Maka proses pembelajaran khususnya materi karate dikemas menjadi sebuah permainan yang berada di dalam aplikasi bernama Articulate Storyline yang telah dijelaskan oleh peneliti. Media pembelajaran ini dapat menunjang pembelajaran bagi pendidik agar dalam proses pembelajaran lebih efisien, meningkatkan daya tarik atau minat belajar siswa, menghindari siswa dari kebosanan dan dapat meningkatkan hasil belajar serta prestasi siswa dalam mata pelajaran pendidikan jasmani, olahraga dan kesehatan.

Peneliti menggunakan subjek KKG PJOK SD Kecamatan Sukun untuk melakukan penelitian guna menyelesaikan syarat mata kuliah skripsi. Dengan jumlah subjek sebanyak 25 orang guru PJOK SD dilakukan analisis kebutuhan dengan menyebarkan angket pada tanggal 22 Juli 2020 dengan menyebar angket melalui google formulir, maka diperoleh hasil bahwa $100 \%$ pendidik memberikan materi tentang beladiri karate. Sebanyak $100 \%$ peserta didik antusias jika pembelajaran materi beladiri karate diajarkan melalui permainan. Sebanyak $60 \%$ pendidik tidak pernah menggunakan aplikasi dalam proses pembelajaran materi beladiri karate. Sebanyak $88 \%$ pendidik tidak pernah menggunakan aplikasi articulate storyline dalam proses belajar mengajar, dan hanya $20 \%$ pendidik yang mengetahui tentang aplikasi articulate storyline dalam proses belajar mengajar. Sebanyak $80 \%$ pendidik menjawab dengan adanya aplikasi dalam proses pembelajaran materi beladiri karate dapat mempermudah guru dalam menyampaikan materi pembelajaran. Sebanyak 100\% KKG PJOK Sekolah Dasar Kecamatan Sukun Kota Malang setuju apabila diadakannya penelitian Pengembangan Media Pembelajaran Aplikasi Tentang Variasi Permainan Karate untuk KKG PJOK Sekolah Dasar Kelas IV Kecamatan Sukun Kota Malang. Sedangkan hasil wawancara yang dilakukan kepada ketua KKG PJOK SD Kecamatan Sukun didapatkan hasil bahwa selama daring pembelajaran hanya dilakukan melalui Whatsapp saja, dan dirasa kurang efektif, oleh karenanya pendidik membutuhkan media untuk proses belajar mengajar yang tepat dan menarik, selain itu siswa juga antusias jika diberikan materi karate melalui permainan, tentunya permainan-permainan yang baru 
juga akan membuat siswa tertarik dan antusias dalam menerima materi, karena terkadang permainan yang sering dilakukan membuat mereka kurang antusias.

Beberapa penelitian dan pengembangan terdahulu yang sejenis,yaitu penelitian (Anggriawan, 2019) yang berjudul "Pengembangan Pembelajaran Teknik Dasar Guling Depan dan Guling Belakang Pada Senam Lantai Melalui Multimedia Interaktif Untuk Kelas VII SMP Negeri 1 Sumberpucung Kabupaten Malang", Hasil penelitian ini menyatakan bahwa dengan adanya penyampaian materi berupa salah satunya video dalam pembelajaran dapat membantu proses belajar dan siswa lebih memahami materi teknik dasar senam lantai yaitu guling depan dan guling belakang produk multimedia interaktif ini dapat dijadikan media pembelajaran oleh guru dan sumber belajar mandiri siswa, produk pembelanjaan ini akan mempermudah pendidik dalam menyampaikan materi. Penelitian yang serupa juga yaitu skripsi (Salam, 2017) yang berjudul "Pengembangan Multimedia Pembelajaran Interaktif Menggunakan Articulate Storyline 2 Pada Mata Pelajaran IPS Materi Keadaan Alam Indonesia Kelas VII Tahun Ajaran 2016/2017 Di MTS Negeri Sumbang Kabupaten Banyumas". Dari hasil penelitian tersebut menyatakan bahwa produk pengembangan menggunakan Articulate Storyline 2 dapat membantu pendidik dalam menyampaikan materi dan dapat diterapkan dalam proses belajar mengajar. Karena pengembangan produk ini sudah melewati metode pengembangan sesuai dengan prosedur dan divalidasi oleh para ahli dan mendapatkan kesimpulan, pengembangan media pembelajaran Articulate Storyline 2 termasuk dalam kategori sangat baik menurut para ahli yaitu ahli media dan ahli materi.

Dengan adanya masalah yang sudah ada dan sudah dibahas sebelumnya terdapat keunggulan dari pembelajaran melalui media aplikasi yang mempermudah proses interaksi antara guru dan siswa. Dalam proses pembelajaran pendidik akan lebih kreatif dalam menyampaikan materi melalui media aplikasi contohnya dalam pembelajaran olahraga, siswa akan semakin tertarik dengan pelajaran olahraga yang disampaikan oleh guru karena terangkum dalam satu aplikasi yang dapat menampilkan materi dengan background yang disukai oleh siswa dan video pembelajaran yang menarik. Aplikasi articulate storyline adalah salah satu aplikasi yang sudah dianggap layak dalam proses belajar mengajar, pendidik dengan lebih mudah menyampaikan materi dalam pembelajaran pendidikan jasmani dan dengan aplikasi ini peserta didik dapat lebih mudah memahami materi yang disampaikan. Berdasarkan latar belakang, maka peneliti akan mengambil jenis penelitian pengembangan yang berjudul "Pengembangan Media Pembelajaran Aplikasi Tentang Variasi Permainan Karate Untuk KKG PJOK Sekolah Dasar Kelas IV di Kecamatan Sukun Kota Malang".

Tujuan dari penelitian ini adalah untuk mengembangkan sebuah produk berupa aplikasi yang dapat digunakan sebagai media pembelajaran yang berisi variasi permainan karate untuk mengatasi beberapa masalah dalam pembelajaran PJOK khususnya pada saat pembelajaran daring yang dikarenakan oleh adanya pandemi virus covid-19.

\section{Metode}

Dalam penelitian pengembangan ini menggunakan model penelitian menurut Lee and Owens (2004) dengan urutan: (1) Analisis yaitu mengumpulkan data yang disebut analisis kebutuhan dengan cara membagikan angket dan wawancara, (2) Desain merupakan tahap perencanaan produk yaitu mengumpulkan bahan-bahan yang dibutuhkan yang nantinya akan dikembangkan, (3) Pengembangan yaitu tahap mengembangkan produk media pembelajaran variasi permainan karate dengan cara mengambil video, merekam audio, memasukkan materi, 
mengedit dan sebagainya. Untuk meninjau validasi dari produk pengembangan aplikasi tentang variasi permainan karate akan dilakukan oleh ahli pembelajaran, ahli media, ahli permainan, ahli PJOK dan ahli karate untuk dapat memperbaiki kekurangan produk, (4) Implementasi yaitu tahap uji coba dan (5) Evaluasi digunakan untuk mengetahui seberapa layaknya produk yang dikembangkan oleh peneliti.

Dalam tahap uji coba produk terdapat (1) Desain uji coba, (2) Subjek uji coba, (3) Jenis data, (4) Instrumen pengumpulan data, (5) teknik analisis data. Desain uji coba terdapat evaluasi ahli yang dilakukan oleh 5 ahli yaitu ahli pembelajaran, ahli media, ahli permainan, ahli PJOK dan ahli karate. Kemudian uji coba kelompok kecil, dan uji coba kelompok besar. Subjek uji coba untuk kelompok kecil yaitu 8 orang guru KKG PJOK SD Kecamatan Sukun Kota Malang, sedangkan subjek uji coba kelompok besar yaitu 17 orang guru KKG PJOK SD Kecamatan Sukun Kota Malang, subjek evaluasi para ahli yaitu 1 ahli pembelajaran, 1 ahli media, 1 ahli permainan, 1 ahli PJOK dan 1 orang ahli karate.

Dalam penelitian ini data yang diperoleh berupa data kualitatif dan kuantitatif. Data kualitatif diperoleh dari hasil evaluasi para ahli dan wawancara dengan ketua KKG PJOK Kecamatan Sukun Kota Malang yang berupa saran-saran dan penjelasan. Data kuantitatif ditemukan dari hasil uji coba kelompok kecil dan hasil uji coba kelompok besar yang berupa angka.

Instrumen yang digunakan dalam penelitian pengembangan ini yaitu observasi awal untuk analisis kebutuhan berupa angket melalui google formulir, angket untuk uji coba kelompok kecil dan uji coba kelompok besar, serta angket untuk para ahli yaitu ahli pembelajaran, ahli media, ahli permainan, ahli PJOK dan ahli karate.

Rumus untuk mengolah data yang berupa analisis deskriptif kuantitatif persentase menurut Akbar \& Sriwiyana (2011), sebagai berikut:

$\mathrm{V}=\frac{\mathrm{TSEV}}{\mathrm{S}-\mathrm{max}} \times 100 \%$

Keterangan:

$\mathrm{V} \quad$ : Validitas

TSEV : : Total skor empirik validator

S-max : Skor maksimal yang diharapkan

$100 \% \quad$ : Bilangan konstanta

Teknik analisis data yang digunakan dalam penelitian dan pengembangan media pembelajaran aplikasi tentang variasi permainan karate untuk KKG PJOK Sekolah Dasar kelas IV di Kecamatan Sukun Kota Malang menggunakan statistik deskriptif. Teknik yang diperoleh untuk pengumpulan data menggunakan Likert. Jawaban dari pertanyaan skala Likert ini mempunyai tingkatan dari sangat positif sampai sangat negatif, untuk jawaban akan mendapatkan skor (4) dengan definisi sangat setuju, (3) setuju, (2) ragu-ragu dan (1) tidak setuju (Sugiyono, 2013). Untuk membantu serta lebih efektif dalam proses pengolahan suatu data hasil analisis berbentuk persentase dan dapat tergolong sesuai dengan persentase yang sudah didapatkan. Menurut Akbar \& Sriwiyana (2011), penggolongan persentase disajikan pada tabel 1. 
Tabel 1. Kriteria Kualitas Produk

\begin{tabular}{ccc}
\hline Kriteria & Keterangan & Makna \\
\hline $75,01 \%-100,00 \%$ & Sangat Valid & Digunakan tanpa revisi \\
$50,01 \%-75,00 \%$ & Cukup Valid & Digunakan dengan revisi kecil \\
$25,01 \%-50,00 \%$ & Tidak Valid & Tidak dapat digunakan \\
$00,00 \%-25,00 \%$ & Sangat Tidak Valid & Terlarang digunakan \\
\hline
\end{tabular}

\section{Hasil dan Pembahasan}

\subsection{Hasil}

Hasil dari pengumpulan data mulai dari analisis kebutuhan, evaluasi para ahli yang dilakukan oleh 5 ahli, uji coba kelompok kecil dan uji coba kelompok besar yaitu data dari evaluasi para ahli yang meliputi saran dari ahli pembelajaran, ahli media, ahli permainan, ahli PJOK dan ahli karate. Data hasil uji coba oleh subjek uji coba yaitu kelompok kecil dan juga kelompok besar didapat dari jawaban dalam instrumen angket yang di isi oleh KKG PJOK SD Kecamatan Sukun Kota Malang sebagai subjek penelitian.

Tabel 2. Hasil Analisis Data Ahli Pembelajaran

\begin{tabular}{llcl}
\hline No. & \multicolumn{1}{c}{ Aspek } & Kelayakan & Kategori \\
\hline 1 & Kejelasan & $73 \%$ & Cukup Valid \\
2 & Ketepatan & $75 \%$ & Cukup Valid \\
3 & Kesesuaian & $75 \%$ & Cukup Valid \\
4. & Kemudahan & $75 \%$ & Cukup Valid \\
5. & Keefektifan & $75 \%$ & Cukup Valid \\
Rata-Rata & $\mathbf{7 5 \%}$ & Cukup Valid \\
\hline
\end{tabular}

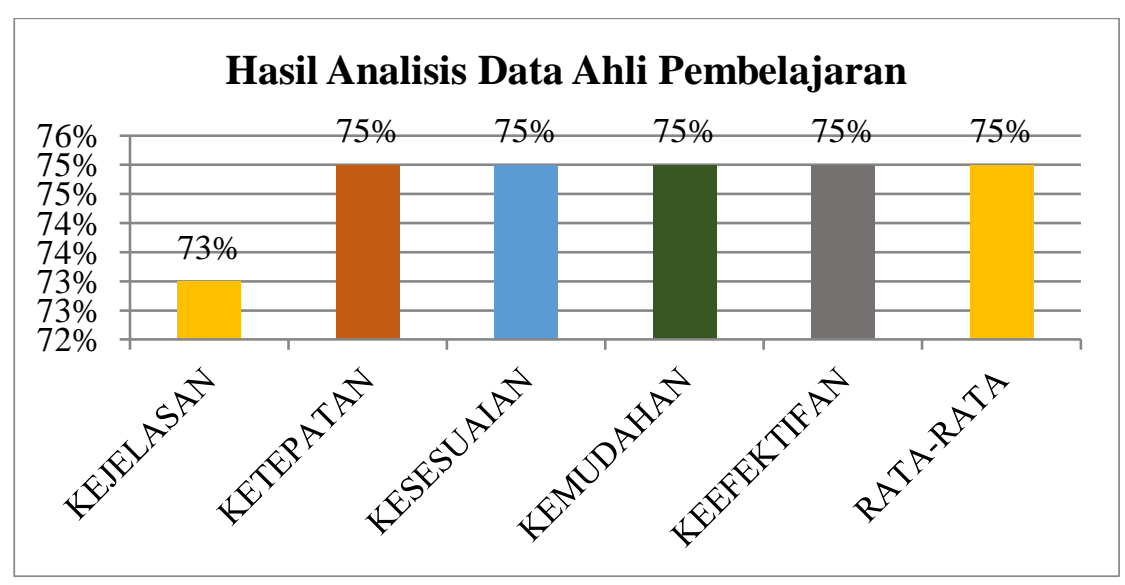

Gambar 1. Diagram Persentase Penilaian Ahli Pembelajaran pada Produk Pengembangan Media Pembelajaran Variasi Permainan Karate yang di Dikemas Dalam Articulate Storyline

Berdasarkan dari aspek kejelasan, ketepatan, kesesuaian, kemudahan dan keefektifan maka didapatkan kesimpulan bahwa produk pengembangan media pembelajaran ini memperoleh presentase $75 \%$ dan dikatakan cukup valid. 
Tabel 3. Hasil Analisis Data Ahli Permainan

\begin{tabular}{llcl}
\hline No. & \multicolumn{1}{c}{ Aspek } & Kelayakan & Kategori \\
\hline 1 & Kesesuaian & $100 \%$ & Sangat Valid \\
2 & Kemampuan & $96 \%$ & Sangat Valid \\
3 & Kemenarikan & $87 \%$ & Sangat Valid \\
4. & Kejelasan & $100 \%$ & Sangat Valid \\
& Rata-Rata & $96 \%$ & Sangat Valid \\
\hline
\end{tabular}

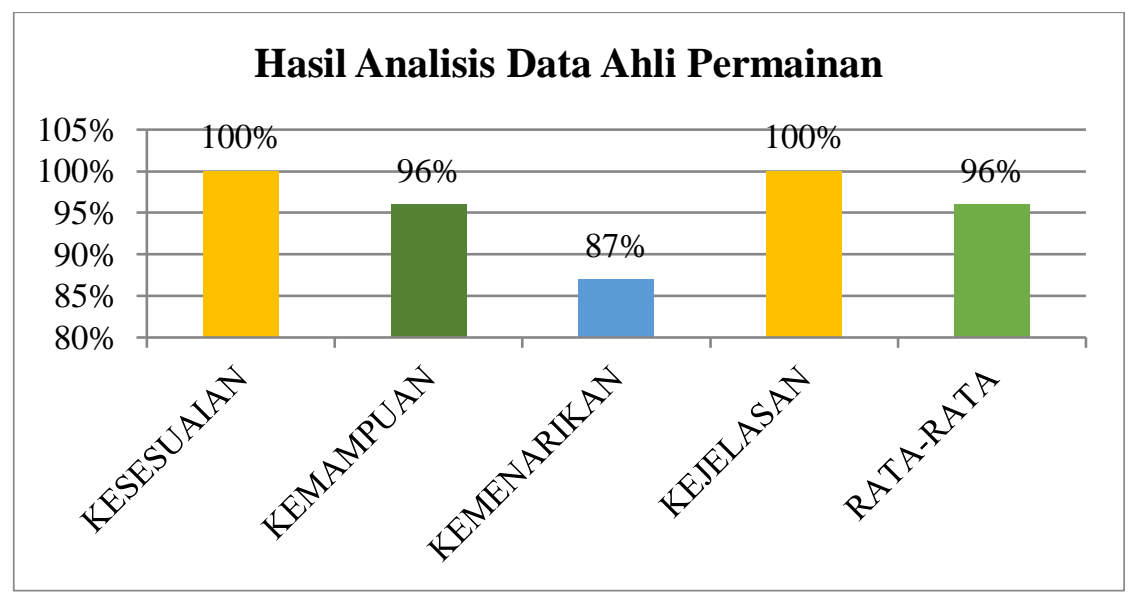

Gambar 2. Diagram Persentase Penilaian Ahli Permainan pada Produk Pengembangan Media Pembelajaran Variasi Permainan Karate yang di Dikemas Dalam Articulate Storyline

Berdasarkan dari aspek kesesuaian, kemampuan, kemenarikan, dan kejelasan maka didapatkan kesimpulan bahwa produk pengembangan media pembelajaran ini memperoleh presentase $96 \%$ dan dikatakan sangat valid.

Tabel 4. Hasil Analisis Data Ahli Media

\begin{tabular}{llcl}
\hline No. & Aspek & Kelayakan & Kategori \\
\hline 1 & Ketepatan & $96 \%$ & Sangat Valid \\
2 & Kemenarikan & $98 \%$ & Sangat Valid \\
3 & Kesesuaian & $97 \%$ & Sangat Valid \\
4. & Kemudahan & $100 \%$ & Sangat Valid \\
Rata-Rata & $\mathbf{9 8 \%}$ & Sangat Valid \\
\hline
\end{tabular}




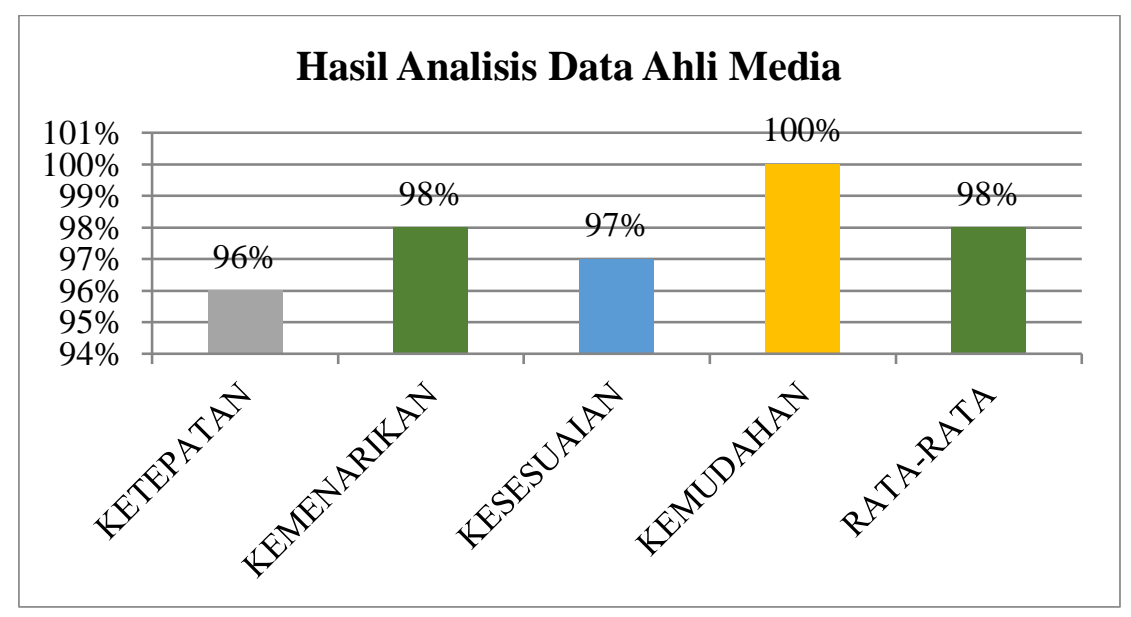

Gambar 3. Diagram Persentase Penilaian Ahli Media pada Produk Pengembangan Media Pembelajaran Variasi Permainan Karate yang di Dikemas Dalam Articulate Storyline

Berdasarkan dari aspek ketepatan, kemenarikan, kesesuaian dan kemudahan maka didapatkan kesimpulan bahwa produk pengembangan media pembelajaran ini memperoleh presentase $98 \%$ dan dikatakan sangat valid.

Tabel 5. Hasil Analisis Data Ahli PJOK

\begin{tabular}{clcc}
\hline No. & Aspek & Kelayakan & Kategori \\
\hline 1 & Kejelasan & $75 \%$ & Cukup Valid \\
2 & Ketepatan & $75 \%$ & Cukup Valid \\
3 & Kesesuaian & $75 \%$ & Cukup Valid \\
4. & Kemudahan & $75 \%$ & Cukup Valid \\
5. & Keefektifan & $75 \%$ & Cukup Valid \\
& Rata-Rata & $\mathbf{7 5 \%}$ & Cukup Valid \\
\hline
\end{tabular}

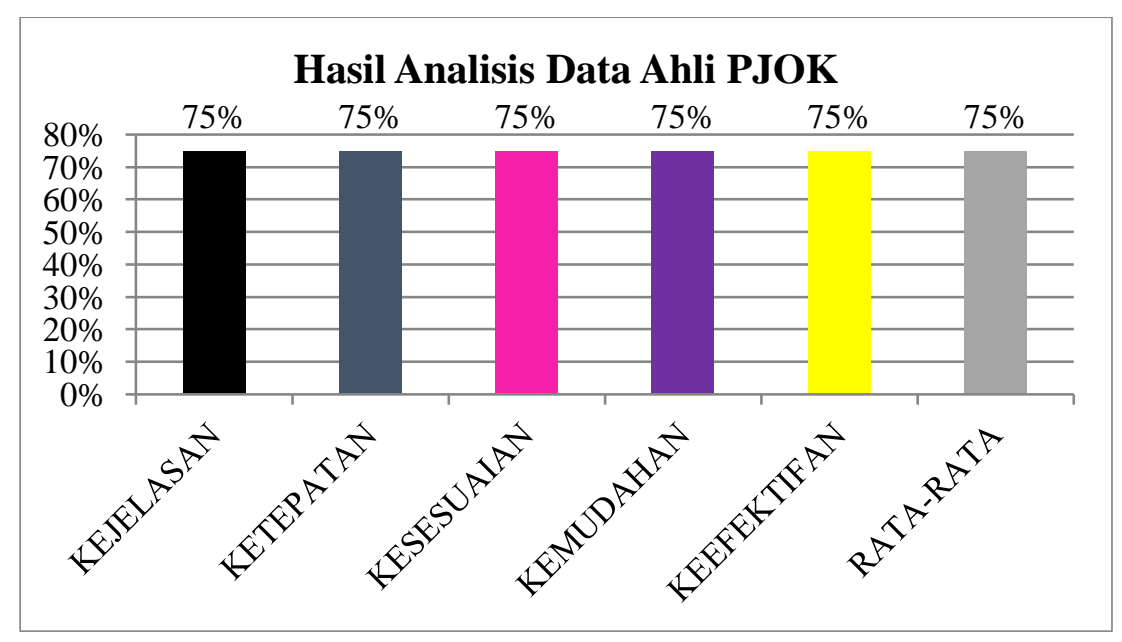

Gambar 4. Diagram Persentase Penilaian Ahli PJOK pada Produk Pengembangan Media Pembelajaran Variasi Permainan Karate yang di Dikemas Dalam Articulate Storyline 
Berdasarkan dari aspek kesesuaian, kejelasan, kemudahan dan ketepatan maka didapatkan kesimpulan bahwa produk pengembangan media pembelajaran ini memperoleh presentase $75 \%$ dan dikatakan cukup valid.

Tabel 6. Hasil Analisis Data Ahli Karate

\begin{tabular}{llcl}
\hline No. & \multicolumn{1}{c}{ Aspek } & Kelayakan & Kategori \\
\hline 1 & Kejelasan & $75 \%$ & Cukup Valid \\
2 & Ketepatan & $75 \%$ & Cukup Valid \\
3 & Kemenarikan & $75 \%$ & Cukup Valid \\
4 & Kemudahan & $75 \%$ & Cukup Valid \\
5 & Kesesuaian & $75 \%$ & Cukup Valid \\
& Rata-Rata & $\mathbf{7 5 \%}$ & Cukup Valid \\
\hline
\end{tabular}

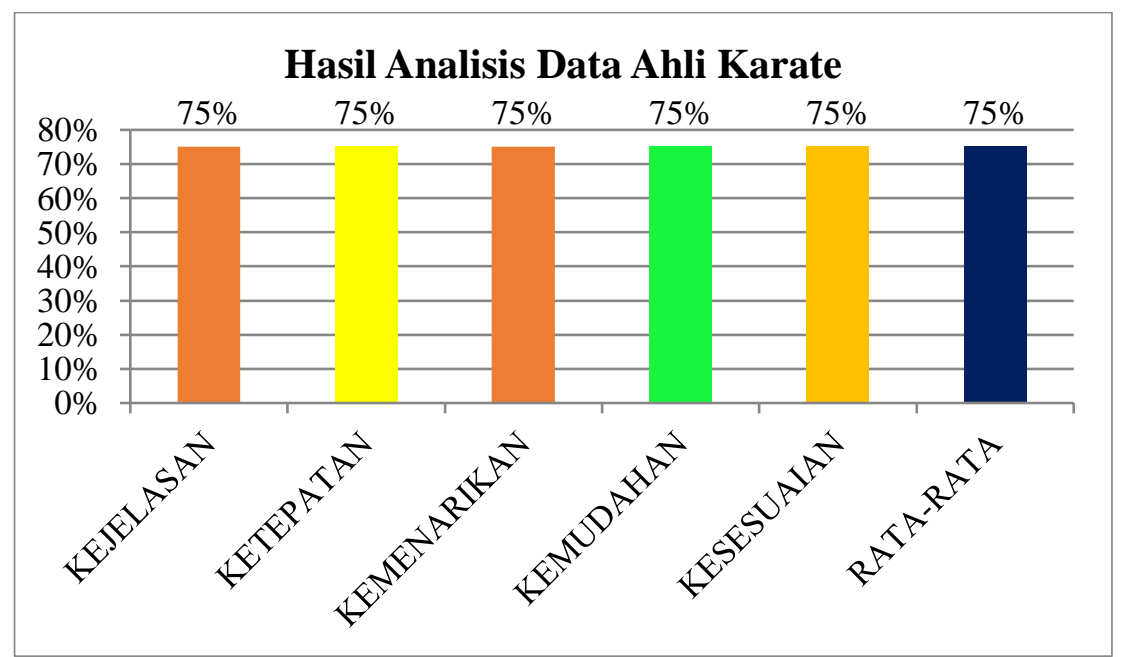

Gambar 5. Diagram Persentase Penilaian Ahli Karate pada Produk Pengembangan Media Pembelajaran Variasi Permainan Karate yang di Dikemas Dalam Articulate Storyline

Berdasarkan dari aspek kejelasan, ketepatan dan kemenarikan, kemudahan, kesesuaian maka didapatkan kesimpulan bahwa produk pengembangan media pembelajaran ini memperoleh presentase $75 \%$ dan dikatakan cukup valid.

Tabel 7. Hasil Analisis Data Uji Coba Kelompok Kecil oleh 8 Orang KKG PJOK Sekolah Dasar di Kecamatan Sukun Kota Malang

\begin{tabular}{clcc}
\hline No. & Aspek & Kelayakan & Kategori \\
\hline 1 & Kemenarikan & $88 \%$ & Sangat Valid \\
2 & Ketepatan & $84 \%$ & Sangat Valid \\
3 & Kesesuaian & $86 \%$ & Sangat Valid \\
4 & Kejelasan & $91 \%$ & Sangat Valid \\
5 & Kemudahan & $84 \%$ & Sangat Valid \\
& Rata-Rata & $\mathbf{8 7} \%$ & Sangat Valid \\
\hline
\end{tabular}




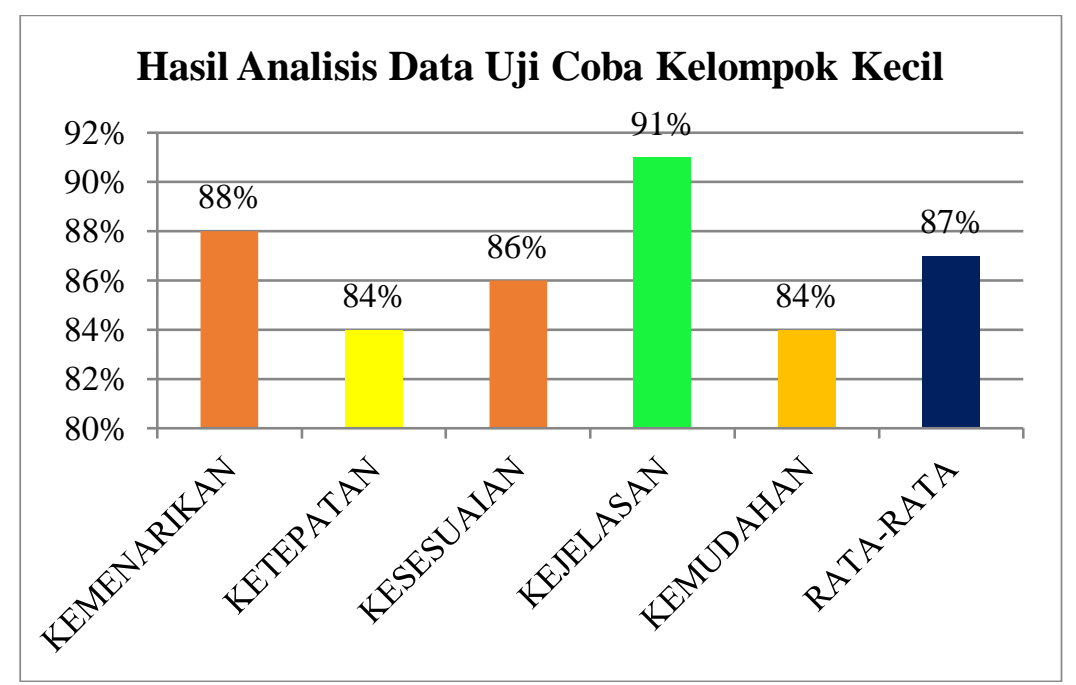

Gambar 6. Diagram Persentase Hasil Data Uji Coba Kelompok Kecil Produk Pengembangan Media Pembelajaran Variasi Permainan Karate yang di Dikemas Dalam Articulate Storyline

Berdasarkan dari aspek kemenarikan, ketepatan, kesesuaian, kejelasan, kemudahan, maka didapatkan kesimpulan bahwa produk pengembangan media pembelajaran ini memperoleh presentase $87 \%$ dan dikatakan sangat valid.

Tabel 8. Hasil Analisis Data Uji Coba Kelompok Besar oleh 17 Orang KKG PJOK Sekolah Dasar di Kecamatan Sukun Kota Malang

\begin{tabular}{clcc}
\hline No. & Aspek & Kelayakan & Kategori \\
1 & Kemenarikan & $89 \%$ & Sangat Valid \\
2 & Ketepatan & $88 \%$ & Sangat Valid \\
3 & Kesesuaian & $89 \%$ & Sangat Valid \\
4 & Kejelasan & $90 \%$ & Sangat Valid \\
5 & Kemudahan & $86 \%$ & Sangat Valid \\
& Rata-Rata & $\mathbf{8 8} \%$ & Sangat Valid \\
\hline
\end{tabular}

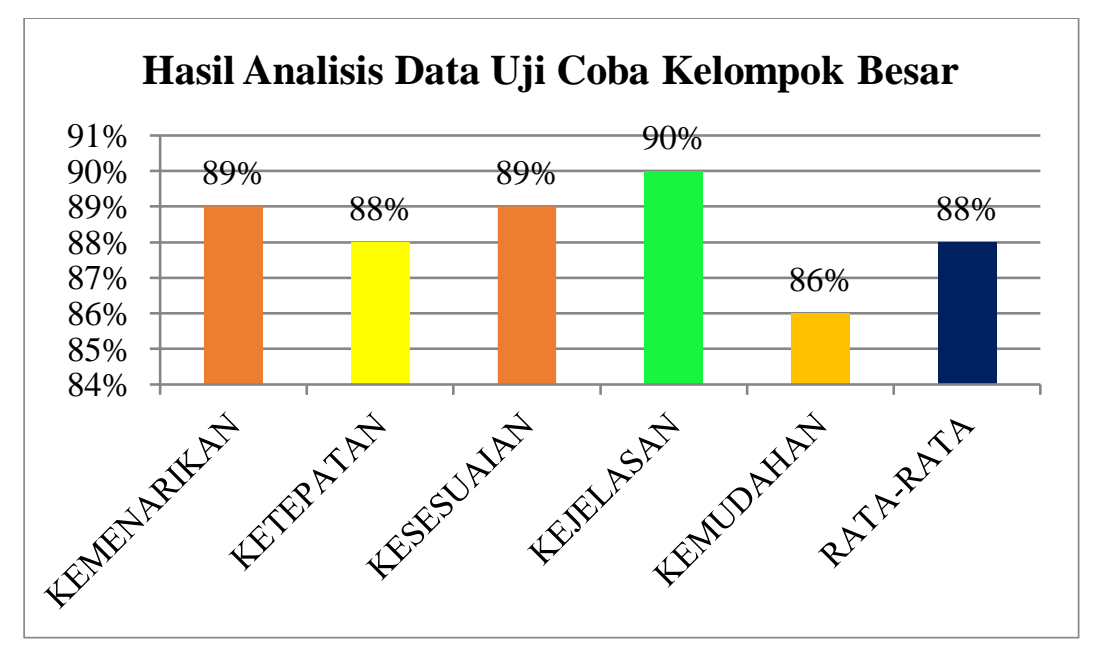

Gambar 7. Diagram Persentase Hasil Data Uji Coba Kelompok Besar Produk Pengembangan Media Pembelajaran Variasi Permainan Karate yang di Dikemas Dalam Articulate Storyline 
Berdasarkan dari aspek kemenarikan, ketepatan, kesesuaian, kejelasan dan kemudahan maka didapatkan kesimpulan bahwa produk pengembangan media pembelajaran ini memperoleh presentase $88 \%$ dan dikatakan sangat valid.

\subsection{Pembahasan}

Produk akhir penelitian ini berupa media pembelajaran variasi permainan karate untuk sekolah dasar kelas IV di Kecamatan Sukun Kota Malang yang menggunakan aplikasi articulate storyline. Pengembangan media pembelajaran yang tepat dan menarik sangat dibutuhkan. Pembelajaran dapat diartikan sebagai bertambahnya wawasan ilmu yang lebih luas untuk menjadi modal ilmu ke jenjang yang lebih tinggi. Menurut (Hanafy, 2014), Pembelajaran merupakan usaha pendidik untuk mewujudkan terjadinya proses pemerolehan pengetahuan, penguasaan kemahiran, dan pembentukan sikap dan kepercayaan pada peserta didik. Dengan kata lain, pembelajaran adalah proses yang memfasilitasi peserta didik agar dapat belajar dengan baik. Sehingga dengan demikian untuk dapat menghasilkan proses pembelajaran yang efektif sebagaimana yang diharapkan, maka pendidik perlu memahami teori-teori belajar yang dapat menjadi landasan pelaksanaan pembelajaran. Menurut (Nasution, 2014), Pembelajaran merupakan kegiatan belajar mengajar yang antara lain dilakukan oleh guru dalam mengkondisikan siswa untuk belajar. 3 Proses pembelajaran merupakan interaksi edukatif yang dilakukan oleh guru dan siswa dalam situasi tertentu. Pelaksanaan proses pembelajaran bukan satu pekerjaan yang mudah dan dapat terjadi begitu saja tanpa direncanakan sebelumnya. Pembelajaran merupakan suatu kegiatan yang mesti direncanakan dan didesain sedemikian rupa mengikuti langkah-langkah dan prosedur tertentu, sehingga pelaksanaannya dapat dicapai hasil yang diharapkan. Menurut (Kirom, 2017) Pembelajaran merupakan sebuah proses menuju kedewasaan yang dilakukan dengan sebuah kegiatan guru mengajar atau membimbing siswa menuju proses pendewasaan yang artinya mengajar tidak serta merta menyampaikan materi, tetapi lebih bagaimana menyampaikan dan mengambil nilai-nilai dari materi yang diajarkan. Dari pendapat para ahli mengenai pembelajaran dapat diambil kesimpulan bahwa pembelajaran adalah proses interaksi peserta didik dengan pendidik dan sumber belajar pada suatu lingkungan belajar untuk mencapai suatu hasil yang optimal.

Media Pembelajaran adalah suatu sarana yang memanfaatkan suatu informasi untuk disampaikan kepada siswa bertujuan membuat siswa memahami dan mengerti tentang informasi tersebut, media pembelajaran dapat menggunakan dua arah yaitu sebagai media mengajar dan belajar yang dapat digunakan oleh siswa itu sendiri. Dengan adanya alat bantu media pembelajaran maka tujuan pembelajaran akan terlaksana dengan baik, karena siswa terdorong untuk belajar. Menurut (Dwijayani, 2019), Media Pembelajaran adalah sebuah alat yang dapat membantu proses belajar mengajar sehingga makna dari sebuah pembelajaran yang disampaikan menjadi lebih jelas dan tujuan pendidikan dapat tercapai dengan efektif dan efisien serta dapat menjelaskan materi pembelajaran dengan urutan yang sistematis dan membantu dalam penyajian materi yang menarik untuk meningkatkan kualitas pembelajaran. Media pembelajaran berperan penting dalam proses interaksi guru dengan siswa. Menurut (Ekayani, 2017), Media pembelajaran merupakan alat bantu pada proses belajar mengajar dengan segala sesuatu yang dapat dipergunakan untuk merangsang pikiran, perasaan, perhatian dan kemampuan siswa sehingga dapat mendorong terjadinya proses belajar. Menurut (Hayes, Hardian, \& Sumekar, 2017), Peran pendidik adalah menyediakan, 
menunjukan, membimbing, dan memotivasi siswa agar mereka dapat melakukan proses belajar mengajar dengan berbagai media pembelajaran yang ada. Media pembelajaran adalah segala sesuatu yang dapat menyalurkan informasi dalam proses belajar mengajar dan dapat disebut sebagai proses komunikasi. Dari beberapa ahli di atas dapat disimpulkan bahwa media pembelajaran merupakan sarana pembawa pesan dari sumber belajar (pendidik) ke penerima pesan belajar (peserta didik) dalam melaksanakan proses pembelajaran, dengan mengikuti perkembangan teknologi maka dapat memotivasi peserta didik dalam proses belajar.

Media yang dikembangkan oleh peneliti berupa aplikasi yaitu Articulate storyline yang merupakan sebuah media pembelajaran yang dapat berupa teks, gambar, audio, video, dan animasi yang bersifat interaktif yang digunakan untuk menyampaikan informasi. Menurut (Surbakti, 2018), Articulate storyline adalah perangkat lunak yang difungsikan sebagai media komunikasi atau presentasi dan memiliki beberapa kelebihan sehingga dapat menghasilkan presentasi yang lebih komprehensif dan kreatif, dan dapat meningkatkan proses belajar siswa. Menurut (Salam, 2017), Articulate Storyline adalah perangkat lunak yang dapat diakses secara offline dan dapat diaplikasikan pada laptop maupun smartphone juga sebagai alat yang berfungsi untuk membantu membangun konten (pembelajaran) yang interaktif. Untuk itu perlu dipelajari bagaimana cara merencanakan sebuah storyline project, menciptakan sebuah presentasi dengan menggunakan semua alat dan elemen yang berbeda, bekerja dengan berbagai media seperti audio dan video, serta menggunakan fasilitas Storyline quiz kemudian publikasikan project yang telah dibuat. Menurut (Nurjanah, 2015), Articulate Storyline merupakan salah satu aplikasi yang digunakan untuk menyampaikan informasi dengan tujuan tertentu dan mempunyai manfaat membuat presentasi terkait dengan kemampuan teknis dan kemampuan seni, serta kolaborasi kedua kemampuan ini dapat menghasilkan presentasi yang menarik sehingga dapat meningkatkan ketertarikan peserta saat mengikuti presentasi. Menurut (Yasin \& Ducha, 2017), Program Articulate Storyline mendukung fitur seperti flash dalam pembuatan animasi. Fitur Articulate Storyline yang lengkap layaknya flash dan interface semudah Power Point menjadikan Articulate Storyline dapat dimanfaatkan sebagai multimedia interaktif. Media ini juga menyediakan berbagai macam template yang bisa digunakan untuk membuat media yang interaktif terutama untuk membuat soal latihan maupun soal tes. Menurut (Habib, 2020), Salah satu media pembelajaran interaktif adalah articulate storyline, software ini dapat digunakan secara offline, sehingga memudahkan para pendidik maupun peserta didik ketika tidak adanya jaringan internet. Pada kondisi saat ini aplikasi articulate storyline sangat mendukung proses pembelajaran, terutama pada mata pelajaran pendidikan jasmani, dan kesehatan serta dapat meningkatkan minat peserta didik dalam proses pembelajaran dirumah. Articulate storyline adalah suatu sistem yang berfungsi sebagai media komunikasi atau presentasi dan terdapat suatu kelebihan sehingga mendapatkan presentasi yang lebih luas dan kreatif untuk menarik minat siswa dalam belajar. Oleh karena itu peserta didik tidak akan merasa bosan dan terbebani oleh tugas yang monoton seperti membaca buku, mengerjakan soal di buku dan merangkum dari buku selama pembelajaran daring ini, sehingga meningkatkan minat siswa dalam proses mengajar khususnya pada mata pelajaran pendidikan jasmani, olahraga, dan kesehatan serta memberikan materi pada guru agar lebih menarik saat melakukan proses belajar mengajar.

Permainan adalah adalah kegiatan yang dirancang untuk mengembangkan kemampuan seseorang untuk menjadikan proses belajar menarik agar siswa melakukan pembelajaran dengan mudah dan rasa senang (Setiawan dan Triyanto 2014). Di dalam media pembelajaran yang berupa aplikasi articulate storyline ini memuat 5 macam permainan yaitu: (1) dachi 
games, (2) maegeri games, (3) lingkaran sehat, (4) oi zuki games dan (5) move winner. Serta di dalam aplikasi juga terdapat evaluasi yang memuat 10 soal-soal latihan yang bisa dikerjakan oleh siswa serta akan didapatkan hasil nilai oleh soal yang telah dikerjakan.

Dengan adanya media pembelajaran yang tepat dan menarik, dan juga macam-macam permainan yang disediakan di dalam aplikasi maka sesuai dengan karakteristik anak usia sekolah dasar menurut (Burhaein, 2017) yaitu masa kanak-kanak berada pada jenjang pendidikan sekolah dasar yang menyukai bermain, menyukai aktivitas yang menggerakkan seluruh anggota tubuh, menggemari aktivitas berkelompok, dan praktik langsung. Maka dari itu di dalam aplikasi juga dimuat macam-macam permainan agar pembelajaran semakin menarik dan meningkatkan semangat belajar siswa. Pendapat lainnya mengatakan bahwa permainan adalah suatu kebutuhan bagi anak yang diperlukan dalam suatu pembelajaran yang dirancang untuk menarik minat belajar siswa terhadap suatu materi dan mengasah kemampuan motorik anak (Kumalasari 2018). Dari beberapa ahli yang sudah ditemukan dapat disimpulkan bahwa permainan adalah salah satu kegiatan menyenangkan yang bisa dilakukan oleh siapa saja, permainan mempunyai 2 macam yaitu permainan tradisional dan modern. Pada saat ini anak-anak lebih mendominasi mengarah pada permainan modern melalui smartphone sehingga kurangnya aktivitas gerak pada anak. Dengan adanya produk media pembelajaran berupa aplikasi yang telah terdapat unsur lengkap yaitu materi karate, macam-macam permainan karate, serta evaluasi bahkan hasil pengerjaan soal dan nilai akan diketahui oleh siswa. Oleh karena itu produk ini akan sangat memudahkan guru dalam kegiatan pembelajaran PJOK kelas IV materi karate. Selain itu siswa juga akan tertarik untuk belajar, dan tidak cepat merasa bosan karena adanya media pembelajaran berupa aplikasi yang dikembangkan oleh peneliti.

Hasil validasi ahli terdapat beberapa saran yaitu saran dari ahli pembelajaran yaitu sebaiknya sejarah diganti dengan teknik dasar karate. Saran dari ahli pembelajaran tersebut telah diperbaiki oleh peneliti pada produk media pembelajaran variasi permainan karate untuk sekolah dasar kelas IV di kecamatan Sukun Kota Malang. Saran dari ahli permainan konsep permainan kurang menarik dan video permainan kurang bagus. Saran dari ahli permainan telah diperbaiki oleh peneliti pada produk media pembelajaran variasi permainan karate untuk sekolah dasar kelas IV di kecamatan Sukun Kota Malang. Kemudian saran dari ahli media yaitu button pada aplikasi ditata rapi dan button karate dan teknik dasar dijadikan satu. Saran dari ahli media telah diperbaiki oleh peneliti pada produk media pembelajaran variasi permainan karate untuk sekolah dasar kelas IV di Kecamatan Sukun Kota Malang. Saran dari ahli karate sebaiknya sarpras dimasukkan pada tampilan langkah-langkah permainan. Saran dari ahli karate telah diperbaiki oleh peneliti pada produk media pembelajaran variasi permainan karate untuk sekolah dasar kelas IV pada Kecamatan Sukun Kota Malang. Saran uji coba yaitu pada tampilan evaluasi soal seharusnya diberikan 4 pilihan yaitu a,b,c,d. Saran dari uji coba kelompok juga sudah diperbaiki oleh peneliti pada produk media pembelajaran variasi permainan karate untuk sekolah dasar yang terdapat pada Kecamatan Sukun Kota Malang.

Hasil produk pengembangan media pembelajaran variasi permainan karate untuk sekolah dasar kelas IV di kecamatan Sukun Kota Malang telah melalui beberapa tahapan revisi dan diperoleh produk terbaik untuk layak digunakan. Produk pengembangan memiliki beberapa kelebihan yaitu: (1) Produk dibuat dengan aplikasi Articulate Storyline yang dapat digunakan secara offline, (2) Berisi tentang bahan ajar berupa video permainan karate yang dikemas secara menarik, (3) Permainan yang terdapat pada aplikasi sudah dimodifikasi 
dengan sarana dan prasarana yang mudah didapat dan (4) Produk pengembangan ini dapat mempermudah guru dalam menyampaikan materi pembelajaran, terutama pada proses pembelajaran online saat ini.

\section{Simpulan}

Hasil dari penelitian dan pengembangan didapatkan kesimpulan bahwa produk media pembelajaran yang di dalamnya memuat materi karate, KI-KD, permainan, evaluasi, biodata dan referensi dinyatakan memiliki kemenarikan, ketepatan, kesesuaian, kejelasan dan kemudahan. Oleh karena itu produk pengembangan layak digunakan oleh guru sebagai media pembelajaran yang akan diberikan atau dibagikan kepada peserta didik.

\section{Daftar Rujukan}

Anggriawan, C. O., Januarto, O. B., \& Kurniawan, A. W. (2019). Pengembangan pembelajaran teknik dasar guling depan dan guling belakang pada senam lantai melalui multimedia interaktif untuk kelas VII SMP negeri 1 Sumberpucung Kabupaten Malang. Motion: Jurnal Riset Physical Education, 10(2), 92-100.

Bangun, S. Y. (2016). Pengembangan Pengetahuan Anak Difabel Melalui Pendidikan Jasmani Olahraga dan Outbound. Journal Physical Education, Health and Recreation, 1(1), 70. https://doi.org/10.24114/pjkr.v1i1.4777

Burhaein, E. (2017). Aktivitas Fisik Olahraga untuk Pertumbuhan dan Perkembangan Siswa SD. Indonesian Journal of Primary Education, 1(1), 51. https://doi.org/10.17509/ijpe.v1i1.7497

Dwijayani, N. M. (2019). Development Of Circle Learning Media To Improve Student Learning Outcomes. Journal of Physics: Conference Series, 1321(2), 171-187. Https://Doi.Org/10.1088/1742$6596 / 1321 / 2 / 022099$

Ekayani, P. (2017). Pentingnya Penggunaan Media. (March). Retrieved From Https://Www.Researchgate.Net/Publication/315105651

Habib, S. A. A. (2020). Potensi Penggunaan Articulate Storyline 3.6 Berbasis E-Learning Terhadap Hasil Belajar Mata Pelajaran Biologi Tingkat SMA Di Era Industri 4.0.

Hanafy, M. S. (2014). Konsep dan Pembelajaran. Lentera Pendidikan, 17(1), 66-79.

Hanief, Y. N., \& Sugito, S. (2015). Membentuk Gerak Dasar Pada Siswa Sekolah Dasar Melalui Permainan Tradisional. Jurnal SPORTIF: Jurnal Penelitian Pembelajaran, 1(1), 60-73. https://doi.org/10.29407/js_unpgri.v1i1.575

Hayes, C., Hardian, H., \& Sumekar, T. (2017). Pengaruh Brain Training Terhadap Tingkat Inteligensia Pada Kelompok Usia Dewasa Muda. Diponegoro Medical Journal (Jurnal Kedokteran Diponegoro), 6(2), 402416.

Kirom, A. 2017. Peran Guru Dan Peserta Didik Dalam Proses Pembelajaran Berbasis Multikultural. Al Murabbi, $3(1), 69-80$

Lee, W., \& Diana L. (2004). Multimedia-Based Instructional Design: Computer-Based Training, Web-Based Training, Distance Broadcast Training, Performance-Based Solutions. John Wiley \& Sons.

Nasution, A. (2014). Perencanaan Pengajaran. Darul Ilmi, 2(1), 1-13.

Nurjanah, S. (2015). Pengaruh Penggunaan Multimedia Articulate Storyline Dalam Meningkatkan Hasil Pembelajaran Fiqih Di Madrasah Aliyah Negeri 3 Kediri

Puspitasari, P., Sari, P., Putri, J., \& Wuryani, W. (2018). Pengaruh Penggunaan Media Pembelajaran terhadap Motivasi Belajar Mahasiswa IKIP Siliwangi. Parole: Jurnal Pendidikan Bahasa Dan Sastra Indonesia, 1(2), 227-232.

Salam, N. A. (2017). Pengembangan Multimedia Pembelajaran Interaktif Menggunakan Articulate Storyline 2 Pada Mata Pelajaran Ips Materi Keadaan Alam Indonesia Kelas Vii Tahun Ajaran 2016/2017 Di Mts Negeri Sumbang Kabupaten Banyumas.

Setiawan, I., \& Triyanto, H. (2014). Pengembagan Permainan Tradisonal Gobak Sodor Bola dalam Pembelajaran Penjas pada Siswa SD. Media Ilmu Keolahragaan Indonesia, 4(1). https://doi.org/10.15294/miki.v4i1.4395 
Surbakti, K., Hotimah, A. K., Ukhwatun, N., Harjono, A., Gunawan, Sutrio, ... Julianto. (2018). Media Pembelajaran Berbasis Articulate Storyline 2 Pada Materi Menggambar Grafik Fungsi Di SMP Patra Dharma 2 Balikpapan Learning Media Based On Articulate Storyline 2 On Drawing Function Graphs Lesson In Smp Patra Dharma 2 Balikpapan. Best Journal (Biology Education, Sains And Technology), 1(1), 242250.

Yasin, A. N., \& Ducha, N. (2017). Kelayakan Teoritis Multimedia Interaktif Berbasis Articulate Storyline Materi Sistem Reproduksi Manusia Kelas XI SMA. Bioedu, 6(2), 249947. 